\title{
Contour Augmentation after Guided Bone Regeneration with Porous Titanium Granules: A Clinical, Histologic and Histomorphometric Evaluation
}

ISSN: 2637-7764

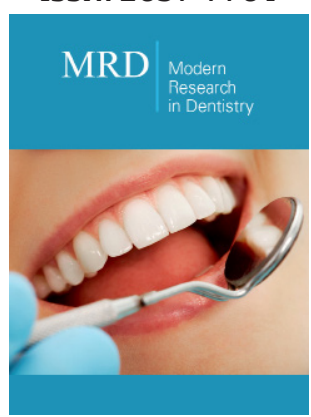

*Corresponding author: Hadi Gholami, Assistant Professor, Department of Prosthodontics, Tufts University, School of Dental Medicine, 1 Kneeland St 02111 Boston, MA, USA

Submission: 觜 February 28, 2020

Published: 悳April 13, 2020

Volume 5 - Issue 1

How to cite this article: GholamAli Gholami, Dieter Bosshardt, Reza Amid, Hadi Gholami, Mahdieh Mirakhori,et al. Contour Augmentation after Guided Bone Regeneration with Porous Titanium Granules: A Clinical, Histologic and Histomorphometric Evaluation. Mod Res Dent. 5(1). MRD.000603.2020.

DOI: 10.31031/MRD.2020.05.000603

Copyright@ Hadi Gholami, This article is distributed under the terms of the Creative Commons Attribution 4.0 International License, which permits unrestricted use and redistribution provided that the original author and source are credited.

\section{GholamAli Gholami ${ }^{1}$, Dieter Bosshardt ${ }^{2}$, Reza Amid ${ }^{3}$, Hadi Gholami ${ }^{4}$ and Mahdieh Mirakhori ${ }^{5}$}

${ }^{1}$ Professor, Department of Periodontics, School of dentistry, Shahid Beheshti University of Medical Sciences, Evin, Tehran, Iran

${ }^{2}$ Professor, Head of the Robert K. Schenk Laboratory of Oral Histology, School of Dental Medicine, University of Bern, Switzerland

${ }^{3}$ Associate Professor, Department of Periodontics, Research Institute for Dental Sciences, School of dentistry, Shahid Beheshti University of Medical Sciences, Evin, Tehran, Iran

${ }^{4}$ Assistant Professor, Department of Prosthodontics, Tufts University, School of Dental Medicine, Boston, MA, USA

${ }^{5}$ Dental Research Center, Research Institute for Dental Sciences, School of dentistry, Shahid Beheshti University of Medical Sciences, Evin, Tehran, Iran

\begin{abstract}
s
Objectives: To determine clinical, histological, and histomorphometrial results following ridge preservation via contour augmentation with high resistance biomaterials.

Material and Methods: A 54-year-old female was referred by her general dentist due to her crowded and periodontally hopeless maxillary right canine and premolar teeth. Two dental implants were surgically placed in palatal positions. The exposed implant surfaces were covered with a slowly-resorbable, synthetic, nanocrystalline hydroxyapatite bone substitute and overbuilding was done with porous titanium granules (PTGs) mixed with the patient's blood. A long-lasting collagen membrane was fixed over the graft sites. Patient was recalled six months later for the second-phase surgery. At that time, a core biopsy from the augmentation site was taken.
\end{abstract}

Result: The patient's cone beam computed tomography scan showed that hard tissue width and height increased from 8.4 and $10.6 \mathrm{~mm}$ to 9.2 and $12.3 \mathrm{~mm}$, respectively. The histological sections revealed that new bone was bridging between the PTGs and neighboring particles. The new bone matrix consisted of $12.41 \%$ mineralized bone matrix and $2.82 \%$ osteoid. Concerning the osteoconductivity of PTGs, $27.0 \%$ new mineralized bone, $10.2 \%$ osteoid, and $62.8 \%$ soft tissue were found covering the titanium particles.

Conclusion: Overbuilding the ridge via contour augmentation with non-resorbable titanium granules could serve as a valid approach based on optimal clinical and biological results.

Clinical Relevance: Immediate implant placement and use of PTGs and collagen membrane all at the same time can improve clinical periodontal parameters and implant stability in the short-term.

Keywords: Guided Bone Regeneration; Contour Augmentation; Ridge preservation; Titanium Granules

\section{Introduction}

Tooth extraction causes inevitable changes in the supporting structures, which may lead to complications for dental implant placement [1]. Since the 1960s, many studies have been conducted to assess the loss of hard and soft tissues after tooth extraction, and innumerable efforts have been made to prevent or minimize bone loss [2]. Different methods have been suggested to preserve and reconstruct bone volume and prevent alveolar ridge resorption following traumatic events such as tooth extraction. The guided bone regeneration (GBR) technique has presented promising results in repairing bone defects. Autogenous bone grafts are considered the gold standard for GBR, due to their osteoconductive, osteoinductive, and osteogenic properties $[3,4]$. Despite their high efficacy for bone reconstruction, the need for 
a second surgical site, unpredictable remodeling rate and bone loss have been regarded as their main disadvantages.

Thus, more recent studies have aimed to find a suitable alternative for autogenous bone grafts. Bone substitutes have found their niche within the field of dentistry and have shown promising results [5-7]. Hydroxyapatite-based materials are commonly used for this purpose. Rothamel et al. [8] evaluated the efficacy of nanocrystalline hydroxyapatite paste; however, he claimed that it is not efficient for ridge preservation due to its unpredictable resorption pattern. Since nonresorbable materials can withstand external loads and are resistant to deformation, they can be used with high success rate in bone defect reconstruction, especially for contour augmentation [5, 7,9-11]. The biocompatibility of titanium has been proven in the recent years, and its use in implant dentistry and orthopedics is widely growing. Titanium is highly resistant to corrosion in body fluids. Furthermore, it is considered a potentially appropriate bone substitute material due to its nonresorbable properties $[10,11]$.

Titanium particles can stimulate the activation of complement system and platelets and can consequently increase the level of platelet-derived growth factor (PDGF). PDGF has been shown to promote bone growth, and this capability along with large surface area is advantageous for bone reconstruction [12]. Porous titanium granules (PTG) (Natix ${ }^{\mathrm{TM}}$, Tigran Technologies AB, Malmo, Sweden) possess these properties and contain $700-1000 \mu \mathrm{m}$ diameter granules. The porous nature of these granules enables bone infiltration between the particles. PTGs consist of irregular, highly porous, nonresorbable granules of commercially pure titanium; they were first introduced for treatment of peri-implant defects. When implanted, the granules are able to interlock with each other, providing a suitable environment for intra- and inter-granule osteogenesis. A stable porous structure is formed as such, which provides an optimal environment for bone ingrowth. Moreover, PTGs have been successfully used in different circumstances within the specialty of implant dentistry. They have also been suggested for management of periodontal furcation involvement of teeth [1315]. On the basis of the mean total amount of regenerated bone, Tavakoli et al. [16] reported that the use of Natix ${ }^{\mathrm{TM}}$ bone substitute with a membrane can promote bone regeneration in the process of healing of extraction sockets in dogs [16]. Considering the valuable characteristics properties of titanium granules as nonresorbable materials, they may be suitable for contour augmentation with different GBR procedures. Therefore, the purpose of this case report was to determine post-extraction dimensional changes following ridge preservation via contour augmentation with PTGs and a collagen membrane for horizontal GBR. As a second objective, the histological composition of the grafted extraction socket was evaluated after 8 months of follow-up.

\section{Material and Methods}

\section{Patient}

A 54-year-old female was referred to our clinic complaining of crowded and periodontally hopeless maxillary right canine and premolar teeth. Due to excessive loss of tooth structure and severe bone loss detected circumferentially, the suggested treatment plan included extraction of teeth (right canine and premolars) and immediate implantation with GBR. Initial cone beam computed tomography data showed that there was no buccal bone plate over the existing teeth (Figure 1).

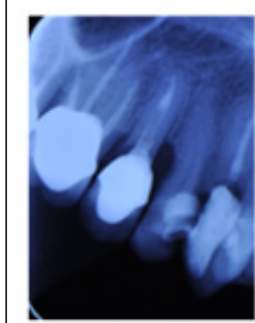

A

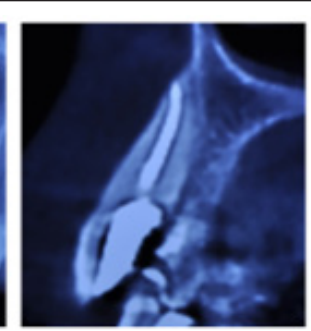

B

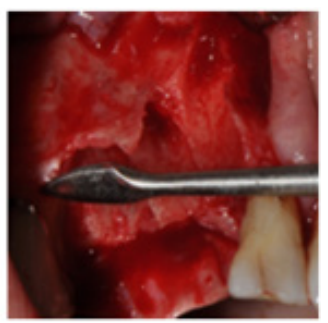

C
Figure 1: (A) Coronal plane of CBCT scan: Bone defect present around maxillary right canine and first and second premolars.

(B) Sagittal plane of CBCT scan: Absence of buccal bone plate over the maxillary right canine.

(C) Clinical view of bone defect around maxillary right canine and first and second premolars after surgical flap elevation and tooth extraction.

\section{Presurgical treatment}

The patient's medical and dental history showed that she had no contraindication for dental implant surgery. The cone beam computed tomography scans, periapical radiographs and clinical photographs were obtained, dental cast was poured, and a clinical periodontal examination was carried out, which included assessment of bleeding on probing (BOP), pocket depth, and plaque index. The patient underwent scaling and root planning and oral hygiene and plaque control instructions were reinforced.

\section{Surgical treatment (stage 1)}

Local anesthesia was administered at the surgical site (buccally and palatally) using 2\% lidocaine with 1:100,000 epinephrine. A sulcular incision was made extending from tooth \#2 to tooth \#6 with a releasing incision at the mesial of tooth \#6. A full thickness mucoperiosteal flap was elevated to expose the labial and palatal bone plate. Interdental papillae were preserved and reflected buccally. The hopeless teeth (canine and premolars) were extracted via a conservative approach using piezo surgery and periotomes. The tooth extraction sockets were then curetted to remove all soft tissue remnants. The bone defects and surgical sites were thoroughly irrigated with sterile saline solution. Two dental implants (4.2x11.5mm SIC max for anterior socket and 4.0x11.5mm SIC ace for posterior socket; SIC, Switzerland) were installed in palatal positions. Due to inadequate buccal bone, 4-8 threads of inserted implants remained exposed. The exposed implant surfaces were covered with a slowly-resorbable, synthetic, nanocrystalline hydroxyapatite bone substitute (NanoBone ${ }^{\circledR}$, Artoss, Germany) and overbuilding was done beyond the resorbed or lost buccal plate with PTGs (Natix ${ }^{\mathrm{TM}}$; Tigran Technologies AB, Malmo, Sweden) mixed with the patient's blood (obtained from a vein). A longlasting collagen membrane (SIC membrane; SIC, Germany) was 
fixed with two tacks (FRIOS bone fixation system, FRIOS, Germany) at the most apical parts in the buccal side and subsequently at the palatal side to firmly cover the entire grafted area. The membrane covered not only the defect site, but also a $3 \mathrm{~mm}$ margin of sound bone at the mesial, distal, apical and palatal.

The flaps were closed with tension-free sutures (3-0 silk) (Figure 2). Postoperatively, the patient was instructed to take $500 \mathrm{mg}$ amoxicillin three times a day for a total of 10 days. Also, $0.2 \%$ chlorhexidine gluconate mouth rinse (DarouPakhsh Holding Co.,
Iran) was prescribed for plaque control, twice daily. The patient's initial postoperative visit was 10 days after surgery; the silk sutures were removed. The patient received professional cleaning on a daily basis alternately between a periodontist and general dentist for the first two weeks. Mechanical oral hygiene practice, consisting of tooth brushing and inter-dental brushing, was initiated by the patient on the $28^{\text {th }}$ post-operative day. Post-operative care included oral hygiene reinforcement and professional plaque removal done on demand.

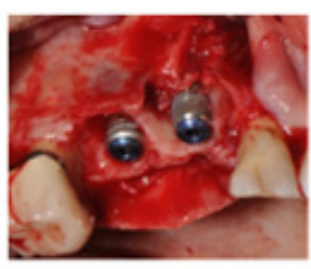

A

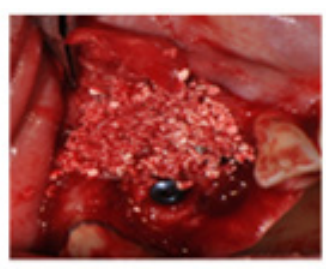

B

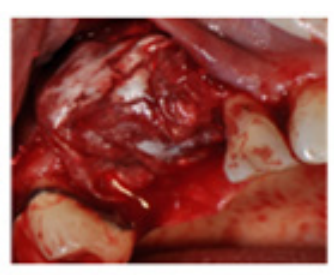

C

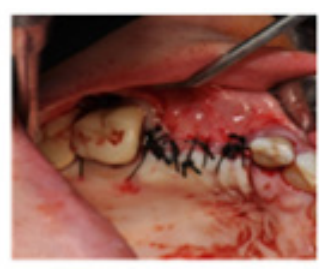

D

Figure 2: (A) Placement of two implants at the sites of maxillary right canine and second premolar teeth.

(B) Covering the buccal bone defect with PTGs.

(C) Placement of collagen membrane over PTGs.

(D) Returning the flap and suturing.

\section{Surgical treatment (stage 2)}

The patient was recalled six months later for the second-phase surgery and uncovering of implants. A $2.7 \mathrm{~mm} \times 6.0 \mathrm{~mm}$ trephine bur was used to take a core biopsy from the augmentation site under copious saline irrigation. The biopsy core was immersed in
$10 \%$ formalin solution. The patient was followed-up weekly until completion of soft tissue healing and then monthly until healing abutment placement (Figure 3). The trephine biopsy core was sent to the Robert K. Schenk Laboratory of Oral Histology (School of Dental Medicine, University of Bern, Switzerland) for histologic and histometric evaluation.

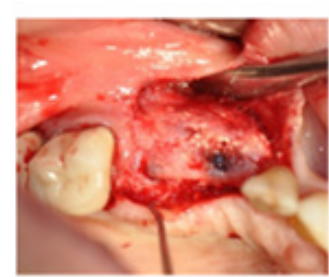

A

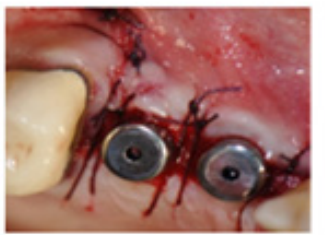

D

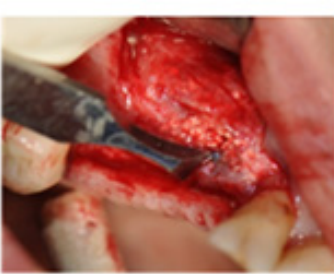

B

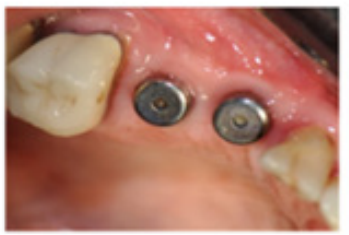

E

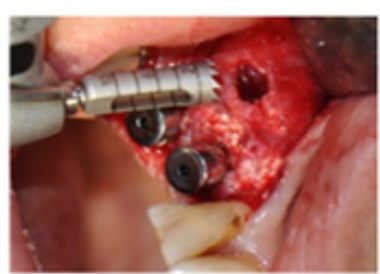

C

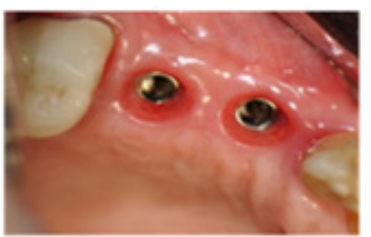

F

Figure 3: (A) Flap elevation in the second-stage surgery.

(B) Uncovering the implants.

(C) Obtaining a core biopsy.

(D) Returning the flap and suturing.

(E) Soft tissue healing six months after surgery.

(F) Opening of healing abutment to place the temporary abutment. 


\section{Sample preparation and descriptive histology}

The specimen was dehydrated in ethanol series and embedded in methyl methacrylate. Undecalcified sections measuring $\sim 500$ microns in thickness were cut using a low speed diamond saw under coolant (Varicut ${ }^{\circledR}$ VC-50, Leco, Munich, Germany). After mounting the sections on acrylic glass slabs, they were ground and polished to a final thickness of about $100 \mu \mathrm{m}$ (Knuth-Rotor-3, Struers, Rodovre/Copenhagen, Denmark). Most sections were stained with toluidine blue and basic fuchsine and the two most central ground sections were used for qualitative and quantitative analyses. A few sections were used for polarized light microscopy. Digital photography was performed using a $\operatorname{Prog} \operatorname{Res}{ }^{\circledR}$ C5 digital camera (Jenoptik Laser, Optik Systeme GmbH, Jena, Germany) connected to a Zeiss Axioplan microscope (Carl Zeiss, Göttingen, Germany). Image processing and morphometric analyses were performed directly under the microscope. One experienced examiner (D.B.) performed descriptive histological analysis.

\section{Histomorphometry}

The area fractions (\%) of the newly formed mineralized bone, osteoid, filler material 1 (PTG), filler material 2 (NanoBone) and soft tissue (ST) occupying the biopsy volume were determined by point counting directly under the microscope, using a square grid (distance between $6 \times 6$ test lines: $0.067 \mathrm{~mm}$ ) at x250 magnification. The percentage of PTG surface covered with the newly formed bone (osteoconduction) was evaluated by counting the intersections using the same grid and magnification as mentioned above.

Result

\section{Clinical results}

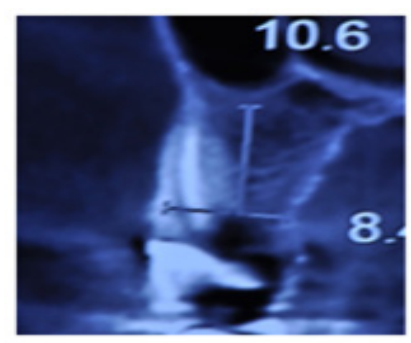

A

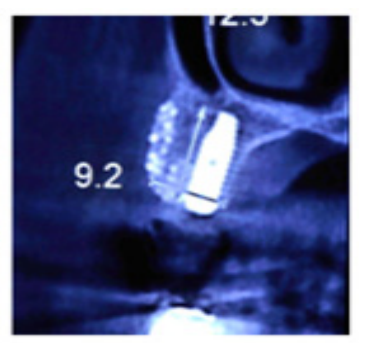

B
Figure 4: (A) Assessment of bone width and height on preoperative CBCT scan of patient;

(B) Assessment of bone width and height on postoperative CBCT scan of patient.

Our patient was a 55-year-old female with no systemic disease, who was referred to our clinic due to failed endodontic treatment of the maxillary right canine and premolar teeth. After extraction of the afore-mentioned teeth due to their hopeless prognosis, two implants were surgically placed at the sites of the maxillary right canine and second premolar. After implant surgery, hard and soft tissue assessment was meticulously done until prosthetic loading of implants six months after the second-stage surgery every two months. During the follow-up sessions, parallel periapical radiographs were obtained, scaling and root planning was performed, and the oral hygiene instructions were given and reinforced. Periodontal parameters including pocket depth, BOP and pus formation were also assessed. Clinical assessment showed no signs of inflammation around the dental implants. Probing depth in the buccal, palatal and interproximal areas of implants was $6 \mathrm{~mm}$ and BOP was present. This value was $3 \mathrm{~mm}$ without BOP or pus after treatment. The patient's cone beam computed tomography scan showed that width and height of bone increased from $8.4 \mathrm{~mm}$ and $10.6 \mathrm{~mm}$ before treatment to $9.2 \mathrm{~mm}$ and $12.3 \mathrm{~mm}$ after treatment, respectively (Figure 4). No signs of graft loss or gingival recession were noted around dental implants.

\section{Histology}

The histological sections revealed the presence of PTGs, new bone, soft tissue and NanoBone ${ }^{\circledR}$ (Figure 5-7). The PTGs were variable in shape, size and density. Most of the new bone was lamellar bone (Figure 6a); however, osteoid lined by osteoblasts was occasionally observed (Figure 6b). The intervening soft tissue was non-fibrous and rich in small and medium-sized blood vessels (Figure 6a,c). New bone was observed in direct contact with PTGs (Figure 6c) and in the pores of PTGs (Figure 6d). Furthermore, new bone was bridging between PTGs and neighboring NanoBone ${ }^{\circledR}$ particles (Figure 7a). The NanoBone ${ }^{\circledR}$ particles were lined by new bone (Figure 7a) and few multinucleated, osteoclast-like, giant cells (Figure 7b). Such multinucleated giant cells were not observed on the PTG surface. The soft tissue peripheral to the NanoBone ${ }^{\circledR}$ particles was cell-rich (Figure 7b).

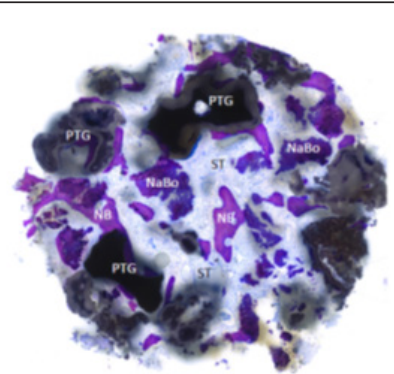

Figure 5: Histological section revealed the presence of PTG: porous titanium granules, NB: new bone, ST: soft tissue, and NaBo: remnant particles of nano hydroxyapatite synthetic bone substitutes.

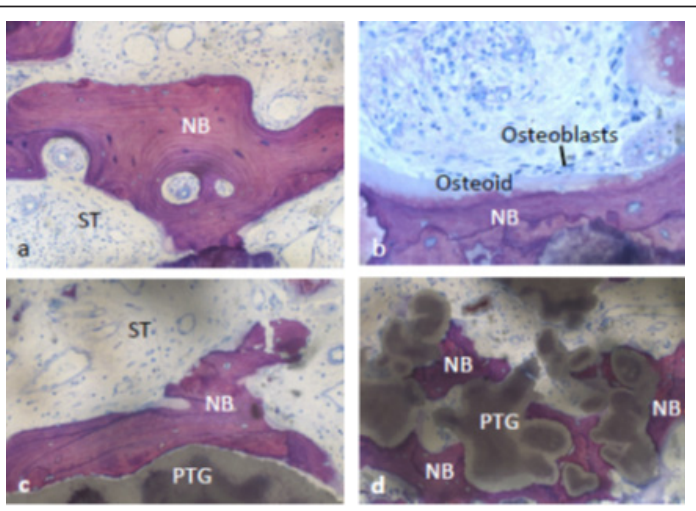

Figure 6: ST: soft tissue and NB: New bone in direct contact with PTGs: porous titanium granules. 


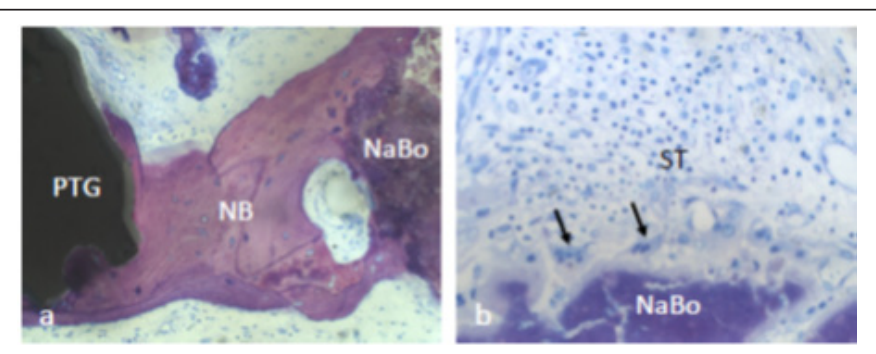

Figure 7: NB: new bone was bridging between PTGs: porous titanium granules and neighboring NaBo: synthetic nano hydroxyl apatite bone substitutes (a). Multinucleated, osteoclast-like, giant cells (arrows) and cell-rich soft tissue were observed peripheral to Nano Bone particles (b).

\section{Histomorphometry}

The area fractions of new bone, soft tissue, PTGs, and NanoBone ${ }^{\circledR}$ were $15.2 \%, 39.3 \%, 22.4 \%$, and $23.1 \%$, respectively (Figure 8a). The new bone matrix consisted of $12.41 \%$ mineralized bone matrix and $2.82 \%$ osteoid. Concerning the osteoconductivity of PTGs, $27.0 \%$ new mineralized bone, $10.2 \%$ osteoid, and $62.8 \%$ soft tissue were found to cover the titanium particles (Figure 8b).

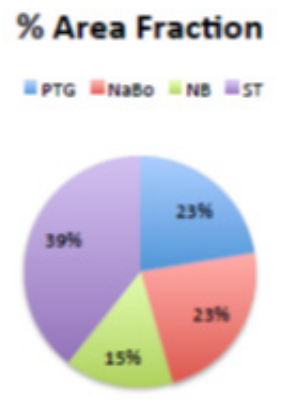

a

\section{Osteoconductivity}

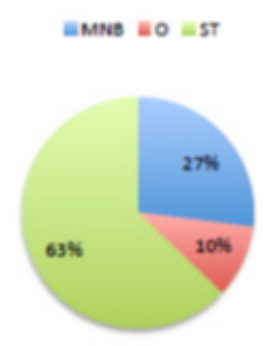

b

Figure 8: The area fractions of NB: new bone, ST: soft tissue, PTGs: porous titanium granules, and NaBo: NanoBone (a). The new bone matrix consisted of MNB: mineralized bone matrix, ST: soft tissue, and O: osteoid (b).

\section{Discussion}

In this case study, PTGs were used to cover the bone defect in the buccal surface of implants in the first phase of surgery. PTGs were first introduced by Bystedt et al. [17] as an osteoconductive material for bone grafting in sinus floor augmentation surgery [17]. Today, PTGs are used for treatment of bone defects [18], inflammatory peri-implant defects [19] and healing of tooth extraction sockets [20]. In our study, some clinical periodontal parameters such as pocket depth, BOP and pus formation were assessed at baseline and every two months after the second-stage surgery. Wohlfahrt et al. [21] reported that clinical attachment level and gingival recession were not significantly different from the baseline values 12 months after treatment of grade II furcal defects of mandibular molars with PTG, but pocket depth and gingival index significantly decreased after treatment and BOP remained unchanged [14]. An animal study by Wohlfahrt et al. [21] showed that probing depth increased six weeks after treatment of grade II furcal defects with PTGs compared to baseline, but gingival index decreased after treatment. Horizontal probing depth was lower in group treated with PTGs compared to the deproteinized bovine bone mineral and sham groups, although the difference between the groups was not significant [21].

In our study, pocket depth was $6 \mathrm{~mm}$ before treatment and BOP was present in the areas with bone loss around teeth. After implant placement and bone grafting, pocket depth improved to $3 \mathrm{~mm}$ and BOP was no longer present. For bone grafting and dental implant placement, graft material may be applied before or simultaneously with placement of dental implants at the site of bone loss. Applying bone graft material prior to implant placement requires an additional surgical procedure, and the associated risks and costs must be taken into account. In our study, bone grafting and dental implant placement were done simultaneously. Table 1 [22-34] lists some studies that used this technique with different bone graft materials. In all the studies listed in Table 1 [22-34], this technique yielded favorable radiographic and clinical results. This technique eliminates the need for an additional surgical procedure; however, there is a risk of implant movement and subsequent movement of graft material. Therefore, this technique requires high precision, and immediate loading of implants is not encouraged and should be avoided.

Moreover, stable bone graft materials must be used. In our study, implant loading was performed six months after the secondstage surgery and a resorbable membrane was placed over PTGs for further stabilization. In most of the studies listed in Table 1 [22-34], GBR technique was used for bone grafting. The results of a review study by Aghaloo et al. [35] showed that the implant survival rate in GBR technique for augmentation of edentulous maxillary ridge was between $96.1-100 \%$, which was slightly higher than that of other technique [36]. Also, collagen membrane was used in the majority of the studies cited in Table 1 and also in our study. Collagen membrane has excellent biocompatibility [37] and more flexibility than ePTFE and titanium mesh [38] and does not need additional surgery for its removal. It appears that use of membrane along with regenerative material enhances the short- 
term results of bone augmentation since Delgado Ruiz et al. [39] showed that six weeks after bone defect coverage using PTGs along with collagen membrane, the percentage of cortical defect closure was significantly higher than that of the PTG group without the collagen membrane. In the PTG group without collagen membrane, evidence of tissue inflammation was noted [40]. Roos et al. [41] stated that use of resorbable membrane along with bone substitute had no significant difference from the use of bone substitute alone for treatment of peri-implantitis defects with regard to the improvement of clinical and radiographic parameters in long-term (5 years) [42]. The above-mentioned findings indicate that as long as the membrane has not been resorbed, it protects bone graft materials against movement and degradation and can therefore enhance the short-term results [43,44].

Table 1: Studies on simultaneous placement of implant and different bone graft material.

\begin{tabular}{|c|c|c|c|c|c|c|c|}
\hline & Author/Year & Study Groups & Graft Material & $\begin{array}{l}\text { Immediate } \\
\text { or Delayed } \\
\text { Implantation }\end{array}$ & $\begin{array}{c}\text { Implant } \\
\text { Placement } \\
\text { Surgical } \\
\text { Technique }\end{array}$ & $\begin{array}{l}\text { Human/Animal } \\
\text { Study }\end{array}$ & Study Design \\
\hline 1 & $\begin{array}{l}\text { Janner, et al. } \\
\text { [36] }\end{array}$ & $\begin{array}{c}1-A+D+M \\
2-A+D \\
3-D+M \\
4-D\end{array}$ & $\begin{array}{c}\text { A: autogenous bone chips, } \\
\text { D: DBBM, M: collagen } \\
\text { membrane }\end{array}$ & Delayed & - & Animal & preclinical study \\
\hline \multicolumn{8}{|c|}{ Result: Addition of autogenous bone chips and presence of collagen membrane increased bone formation around DBBM particles. } \\
\hline 2 & $\begin{array}{l}\text { Wessing, et al. } \\
{[37]}\end{array}$ & $\begin{array}{c}\text { 1- CXP } \\
\text { 2- Reference membrane (BG) }\end{array}$ & $\begin{array}{l}\text { Creos Xenoprotect } \\
\text { reference membrane }\end{array}$ & - & Two-stage & Human & RCT \\
\hline
\end{tabular}

Result: In the CXP arm, the mean defect height at implant insertion site was $5.1 \pm 2.1 \mathrm{~mm}(\mathrm{n}=24)$, which decreased at reentry by $81 \%$ to $1.0 \pm 1.3 \mathrm{~mm}$ ( $\mathrm{n}=23)$. In the BG arm, the defect height at implant insertion site was $4.9 \pm 1.9 \mathrm{~mm}(\mathrm{n}=25)$ and reduced at reentry by $62 \%$ to $1.7 \pm 2.1 \mathrm{~mm}(\mathrm{n}=24)$.

\begin{tabular}{|c|c|c|c|c|c|c|c|}
\hline 3 & Benic, et al. [38] & $\begin{array}{c}\text { 1-GBR: } \\
\text { DBBM+AB+CM } \\
\text { 2-Standard implant } \\
\text { placement without GBR }\end{array}$ & $\begin{array}{l}\text { DBBM, autogenous bone, } \\
\text { collagen membrane }\end{array}$ & - & - & Human & 15 -year results \\
\hline
\end{tabular}

Result: Implants placed with simultaneous GBR by using particulate DBBM and/or AB in combination with CM did not significantly differ from implants completely placed into pristine bone with respect to 15-year implant survival, interproximal bone levels, and dimensions of buccal bone and mucosa.

\begin{tabular}{|c|c|c|c|c|c|c|c|c|}
\hline 4 & $\begin{array}{c}\text { Benic, et al. } \\
{[40]}\end{array}$ & $\begin{array}{c}\text { 1- Without GBR } \\
\text { 2- With GBR }\end{array}$ & $\begin{array}{c}\text { DBBM, collagen } \\
\text { membrane }\end{array}$ & Delayed & Human & Prospective study \\
\hline \multicolumn{5}{|c|}{ Result: Implant placement with simultaneous GBR resulted in more gain of buccal soft tissue contour in comparison with implant placement without GBR. } \\
\hline 5 & $\begin{array}{c}\text { Gultekin, et al. } \\
{[42]}\end{array}$ & $\begin{array}{c}\text { 1- Autogenous iliac bone } \\
\text { grafting }\end{array}$ & $\begin{array}{c}\text { Autogenous iliac bone } \\
\text { grafting, nonresorbable } \\
\text { 2- Nonresorbable membrane }\end{array}$ & $\begin{array}{c}\text { metrospective } \\
\text { study }\end{array}$ & - & Human \\
\hline
\end{tabular}

Result: Although both hard tissue augmentation approaches provide an adequate volume of bone graft for implant insertion, IBG results in greater graft resorption at maxillary augmented sites than GBR.

\begin{tabular}{|c|c|c|c|c|c|c|c|}
\hline 6 & $\begin{array}{c}\text { Demarosi, et al. } \\
{[22]}\end{array}$ & $\begin{array}{c}\text { Regenerative materials and } \\
\text { a barrier }\end{array}$ & $\begin{array}{c}\text { regenerative materials } \\
\text { and a barrier }\end{array}$ & Immediate & Human & A Technical Note \\
\hline \multicolumn{7}{|c|}{ Result: This procedure preserves the apical ridge bone crest, allowing implant anchorage and primary stability to be achieved. } \\
\hline 7 & $\begin{array}{c}\text { Stricker, et al. } \\
{[23]}\end{array}$ & $\begin{array}{c}\text { 1-Mucoperiosteal flap+GBR } \\
\text { 2-Mucosal flap }\end{array}$ & $\begin{array}{c}\text { Biphasic calcium } \\
\text { phosphate, collagen } \\
\text { membrane }\end{array}$ & - & Animal & Preclinical study \\
\hline 8 & $\begin{array}{c}\text { Kolerman, et al. } \\
{[24]}\end{array}$ & $\begin{array}{c}\text { Mineralized allograft (FDBA), } \\
\text { collagen membrane }\end{array}$ & $\begin{array}{c}\text { Mineralized allograft } \\
\text { (FDBA), collagen } \\
\text { membrane }\end{array}$ & Immediate & One-stage & Human & $\begin{array}{c}\text { Retrospective } \\
\text { study }\end{array}$ \\
\hline
\end{tabular}

Result: During the follow up period, the study group presented a mean mesial bone loss of $1.10 \pm 0.39 \mathrm{~mm}$, and mean distal bone loss was $1.19 \pm 0.41 \mathrm{~mm}$. Anterior

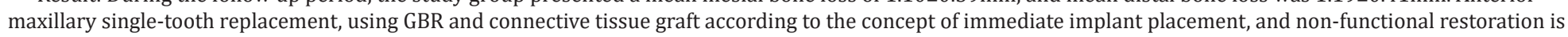
an accepted treatment modality achieving favorable peri-implant soft tissue condition.

\begin{tabular}{|c|c|c|c|c|c|c|c|}
\hline 9 & Jung, et al. [25] & $\begin{array}{ll}\text { 1- } & \text { Xenogeneic bone } \\
\text { mineral+ CM } \\
\text { 2- } & \text { Xenogeneic bone } \\
\text { mineral+ PEG }\end{array}$ & $\begin{array}{c}\text { Xenogeneic bone mineral, } \\
\text { collagen membrane, } \\
\text { polyethylene glycol } \\
\text { membrane }\end{array}$ & - & - & Human & RCT \\
\hline \multicolumn{8}{|c|}{ 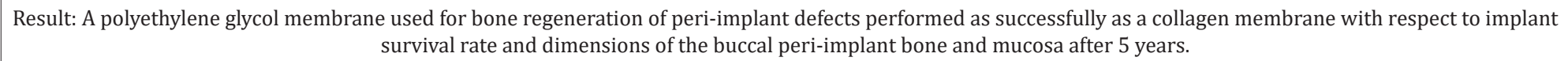 } \\
\hline 10 & $\begin{array}{c}\text { Konstantinidis, } \\
\text { et al. [26] }\end{array}$ & $\begin{array}{ll}1- & \mathrm{CPS}+\mathrm{CM} \\
2- & \mathrm{CPS}+\mathrm{TM}\end{array}$ & $\begin{array}{l}\text { Calcium Phosphosilicate, } \\
\text { alloplastic bone putty, } \\
\text { collagen membrane, } \\
\text { titanium mesh }\end{array}$ & Delayed & Two-stage & Human & Case series \\
\hline
\end{tabular}




\begin{tabular}{|c|c|c|c|c|c|c|c|}
\hline 11 & $\begin{array}{l}\text { Covani, et al. } \\
\text { [27] }\end{array}$ & $\begin{array}{l}\text { Porcine bone, collagen } \\
\text { membrane }\end{array}$ & $\begin{array}{l}\text { Porcine bone, collagen } \\
\text { membrane }\end{array}$ & Immediate & - & Human & $\begin{array}{l}\text { Single-cohort } \\
\text { study }\end{array}$ \\
\hline \multicolumn{8}{|c|}{$\begin{array}{l}\text { Result: The data of this study suggested that the placement of a dental implant by means of a flapless technique in a fresh extraction socket filled with slowly } \\
\text { resorbable graft biomaterial and with a delayed prosthetic restoration shows positive final esthetic outcomes. At the } 5 \text {-year point of the survey, the changes in the } \\
\text { bone level were minimal. Moreover, both midfacial tissue and the papillae maintained the early increase recorded before the first year of the follow-up. }\end{array}$} \\
\hline 12 & $\begin{array}{l}\text { Noelken, et al. } \\
\text { [28] }\end{array}$ & Autogenous bone chips & Autogenous bone chips & Immediate & - & Human & 2-year results \\
\hline \multicolumn{8}{|c|}{$\begin{array}{l}\text { Result: Even implant sites with facial bone defects can be successfully treated with a favorable esthetic outcome using the immediate implant insertion, immediate } \\
\text { reconstruction, and immediate provisionalization technique. }\end{array}$} \\
\hline 13 & $\begin{array}{l}\text { Cucchi, et al. } \\
\qquad[29]\end{array}$ & $\begin{array}{c}\text { Heterologous porcine- } \\
\text { derived biomaterial, } \\
\text { high-density } \\
\text { polytetrafluoroethylene }\end{array}$ & $\begin{array}{l}\text { Heterologous porcine- } \\
\text { derived biomaterial, } \\
\text { high-density } \\
\text { polytetrafluoroethylene }\end{array}$ & Delayed & Two-stage & Human & Case report \\
\hline \multicolumn{8}{|c|}{$\begin{array}{l}\text { Result: the use of a heterologous bone substitute alone to restore a vertical defect in a GBR procedure can be as effective as the standard protocol, while avoiding the } \\
\text { drawbacks associated with a second surgical site opening. }\end{array}$} \\
\hline 14 & Jung, et al. [30] & $\begin{array}{l}\text { 1- } \quad \text { DBBM+CM } \\
\text { 2- } \mathrm{DBBM}+\mathrm{e}-\mathrm{PTFE} \\
\text { 3- Control }\end{array}$ & $\begin{array}{l}\text { DBBM, collagen } \\
\text { membrane, Expanded } \\
\text { polytetrafluoroethylene }\end{array}$ & - & - & Human & Original study \\
\hline 15 & $\begin{array}{l}\text { Favero, et al. } \\
\quad[31]\end{array}$ & $\begin{array}{l}\text { 1- } \mathrm{DBBM}+\mathrm{CM} \\
\text { 2- } \quad \text { Control }\end{array}$ & $\begin{array}{l}\text { DBBM, collagen } \\
\text { membrane }\end{array}$ & Immediate & - & Animal & $\begin{array}{l}\text { Experimental } \\
\text { study }\end{array}$ \\
\hline
\end{tabular}

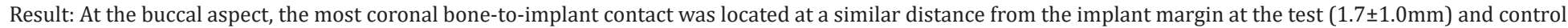

$(1.6 \pm 0.8 \mathrm{~mm})$ sites, respectively. The use of DBBM particles, concomitantly with a collagen membrane, did not additionally improve the outcome obtained at the control sites.

\begin{tabular}{|c|c|c|c|c|c|c|c|}
\hline 16 & $\begin{array}{c}\text { Caneva, et al. } \\
{[32]}\end{array}$ & $\begin{array}{c}\text { 1-DBBM+CM } \\
\text { 2-No treatment augmentation }\end{array}$ & $\begin{array}{l}\text { DBBM, collagen } \\
\text { membrane }\end{array}$ & Immediate & - & Animal & $\begin{array}{l}\text { Experimental } \\
\text { study }\end{array}$ \\
\hline
\end{tabular}

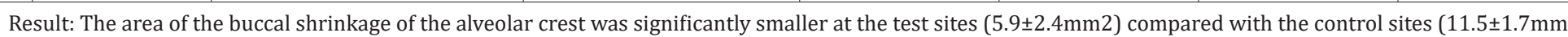

(2)). After 4 months of healing, no differences in soft tissue dimensions were found between the test and control sites based on the histological assessments.

\begin{tabular}{|c|c|c|c|c|c|c|c|}
\hline 17 & $\begin{array}{l}\text { Shibly, et al. } \\
\text { [33] }\end{array}$ & $\begin{array}{l}\text { Freeze-dried bone allograft, } \\
\text { collagen membrane }\end{array}$ & $\begin{array}{l}\text { Freeze-dried bone } \\
\text { allograft, collagen } \\
\text { membrane }\end{array}$ & Immediate & - & Human & Case series \\
\hline
\end{tabular}

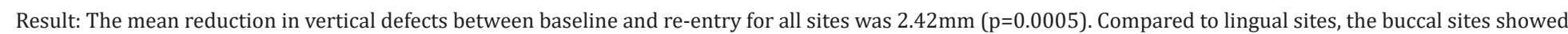

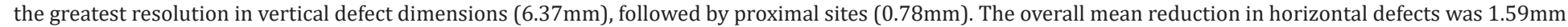

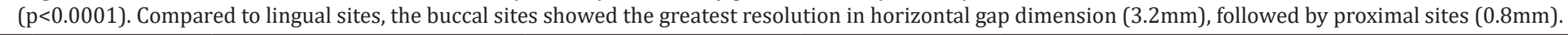

\begin{tabular}{|c|c|c|c|c|c|c|c|}
\hline 18 & Benić, et al. [34] & $\begin{array}{c}\text { 1- Xenogeneic bone substitute } \\
\text { material, autogenous bone } \\
\text { or a mixture of the two } \\
\text { and defect covering with } \\
\text { a bio-absorbable collagen } \\
\text { membrane } \\
\text { 2- Standard implantation } \\
\text { procedure without bone } \\
\text { regeneration }\end{array}$ & $\begin{array}{l}\text { Xenogeneic bone } \\
\text { substitute material, } \\
\text { autogenous bone, bio- } \\
\text { absorbable collagen } \\
\text { membrane }\end{array}$ & - & - & Human & 5-Year results \\
\hline
\end{tabular}

Result: Cumulative survival rates reached $100 \%$ for the GBR group and $94.1 \%$ for the control group without statistical significance. No statistically significant differences for clinical and radiographic parameters were found between the two groups.

\section{Conclusion}

Tooth extraction followed by implant placement and use of PTGs and collagen membrane all at the same time can improve clinical periodontal parameters and implant stability in the shortterm. Long-term randomized clinical trials with large sample size are required in this respect. Moreover, future studies are recommended to compare different bone graft materials for simultaneous placement with implant insertion.

\section{References}

1. Murakami Y, Honda Y, Anada T, Shimauchi H, Suzuki O (2010) Comparative study on bone regeneration by synthetic octacalcium phosphate with various granule sizes. Acta Biomater 6(4): 1542-1548.
2. Rickert D, Slater JJ, Meijer HJ, Vissink A, Raghoebar GM (2012) Maxillary sinus lift with solely autogenous bone compared to a combination of autogenous bone and growth factors or (solely) bone substitutes. A systematic review. Int J Oral Maxillofacial Surg 41(2): 160-167.

3. Neovius E, Engstrand T (2010) Craniofacial reconstruction with bone and biomaterials: review over the last 11 years. J Plast Reconstr Aesthet Surg: JPRAS 63(10): 1615-1623.

4. Rubin JP, Yaremchuk MJ (1997) Complications and toxicities of implantable biomaterials used in facial reconstructive and aesthetic surgery: a comprehensive review of the literature. Plast Reconstr Surg 100(5): 1336-1353.

5. Gottlow J, Nyman S, Lindhe J, Karring T, Wennstrom I (1986) New attachment formation in the human periodontium by guided tissue regeneration. Case reports. J Clin Periodontology 13(6): 604-616. 
6. Papapanou PN, Tonetti MS (2000) Diagnosis and epidemiology of periodontal osseous lesions. Periodontol 2000 22: 8-21.

7. Trombelli L, Mayfield LJ, Needleman I, Moles D, Scabbia A (2002) A systematic review of graft materials and biological agents for periodontal intraosseous defects. J Clinical Periodontology 29 Suppl 3: 117-135.

8. Rothamel D, Schwarz F, Herten M, Engelhardt E, Donath K, et al. (2008) Dimensional ridge alterations following socket preservation using a nanocrystalline hydroxyapatite paste: a histomorphometrical study in dogs. Int J Oral Maxillofac Surg 37(8): 741-747.

9. Lynch SE, Williams RC, Polson AM, Howell TH, Reddy MS, et al. (1989) A combination of platelet-derived and insulin-like growth factors enhances periodontal regeneration. J Clin Periodontol 16(8): 545-548.

10. Reynolds MA, Reidy ME, Mays GL, Gunsolley JC (2003) The efficacy of bone replacement grafts in the treatment of periodontal osseous defects. A systematic review. Ann Periodontology 8(1): 227-265.

11. Shirmohammadi A, Chitsazi MT, Lafzi A (2009) A clinical comparison of autogenous bone graft with and without autogenous periodontal ligament graft in the treatment of periodontal intrabony defects. Clin Oral Investig 13(3): 279-286.

12. Gholami GA, Kadkhodazadeh M, Ardakani M, Tehranchi M, Aghaloo M, et al. (2010) Histologic and histomorphometric evaluation of bone substitutes in experimental defects. Res J Biol Sci 5(7): 465-469.

13. Gholami G, Kadkhodazadeh M (2012) Porous titanium granules for management of a severe intra bony defect. Journal of Clinical Periodontology 39:134.

14. Wohlfahrt JC, Lyngstadaas SP, Heijl L, Aass AM (2012) Porous titanium granules in the treatment of mandibular Class II furcation defects: a consecutive case series. J Periodontol 83(1): 61-69.

15. Wohlfahrt JC, Lyngstadaas SP, Ronold HJ, Saxegaard E, Ellingsen JE, et al. (2012) Porous titanium granules in the surgical treatment of periimplant osseous defects: a randomized clinical trial. International J Oral Maxillofac Implants 27(2): 401-410.

16. Tavakoli M, Moghareabed A, Farsam T, Abbas FM, Badrian H, et al. (2012) Evaluation of dental socket healing after using of porous titanium granules: Histologic and histomorphometric assessment in dogs. Den Res J 9(5): 600-606.

17. Bystedt H, Rasmusson L (2009) Porous titanium granules used as osteoconductive material for sinus floor augmentation: a clinical pilot study. Clin Implant Dent Relat Res 11(2): 101-105.

18. Wohlfahrt JC, Monjo M, Ronold HJ, Aass AM, Ellingsen JE, et al. (2010) Porous titanium granules promote bone healing and growth in rabbit tibia peri-implant osseous defects. Clin Oral Implants Res 21(2): 165173.

19. Mijiritsky E, Yatzkaier G, Mazor Z, Lorean A, Levin L (2013) The use of porous titanium granules for treatment of peri-implantitis lesions: preliminary clinical and radiographic results in humans. $\mathrm{Br}$ Dent J 214(5): E13.

20. Verket A, Lyngstadaas SP, Ronold HJ, Wohlfahrt JC (2014) Osseointegration of dental implants in extraction sockets preserved with porous titanium granules - an experimental study. Clin Oral Implants Res 25(2): e100-108.

21. Wohlfahrt JC, Aass AM, Ronold HJ, Heijl L, Haugen HJ, et al. (2012) Microcomputed tomographic and histologic analysis of animal experimental degree II furcation defects treated with porous titanium granules or deproteinized bovine bone. J Periodontol 83(2): 211-221.

22. Demarosi F, Varoni E, Rimondini L, Carrassi A, Leghissa GC (2016) Immediate implant placement after removal of maxillary impacted canine teeth: A technical note. Int J Oral Maxillofac Implants 31(1): 191194.

23. Stricker A, Fleiner J, Stubinger S, Fleiner H, Buser D, et al. (2016) Ridge preservation after ridge expansion with simultaneous guided bone regeneration: a preclinical study. Clin Oral Implants Res 27(11): e116-e124.

24. Kolerman R, Nissan J, Rahmanov A, Zenziper E, Slutzkey S, et al. (2016) Radiological and biological assessment of immediately restored anterior maxillary implants combined with GBR and free connective tissue graft. Clin Implant Dent Related Res 18(6): 1142-1152.

25.Jung RE, Benic GI, Scherrer D, Hammerle CH (2015) Cone beam computed tomography evaluation of regenerated buccal bone 5 years after simultaneous implant placement and guided bone regeneration procedures--a randomized, controlled clinical trial. Clin Oral Implants Res 26(1): 28-34.

26. Konstantinidis I, Kumar T, Kher U, Stanitsas PD, Hinrichs JE, et al. (2015) Clinical results of implant placement in resorbed ridges using simultaneous guided bone regeneration: a multicenter case series. Clin Oral Investig 19(2): 553-559.

27. Covani U, Canullo L, Toti P, Alfonsi F, Barone A et al. (2014) Tissue stability of implants placed in fresh extraction sockets: a 5-year prospective single-cohort study. J Periodontol 85(9): e323-e332.

28. Noelken R, Neffe BA, Kunkel M, Wagner W (2014) Maintenance of marginal bone support and soft tissue esthetics at immediately provisionalized OsseoSpeed implants placed into extraction sites: 2-year results. Clin Oral Implants Res 25(2): 214-220.

29. Cucchi A, Ghensi P (2014) Vertical guided bone regeneration using titanium-reinforced d-PTFE membrane and prehydrated corticocancellous bone graft. Open Dent J 8: 194-200.

30. Jung RE, Fenner N, Hammerle CH, Zitzmann NU (2013) Long-term outcome of implants placed with guided bone regeneration (GBR) using resorbable and non-resorbable membranes after 12-14 years. Clin Oral Implants Res 24(10): 1065-1073.

31. Favero G, Botticelli D, Favero G, Garcia B, Mainetti T, et al. (2013) Alveolar bony crest preservation at implants installed immediately after tooth extraction: an experimental study in the dog. Clin Oral Implants Res 24(1): 7-12.

32. Caneva M, Botticelli D, Morelli F, Cesaretti G, Beolchini M, et al. (2012) Alveolar process preservation at implants installed immediately into extraction sockets using deproteinized bovine bone mineral-an experimental study in dogs. Clin Oral Implants Res 23(7): 789-796.

33. Shibly O, Kutkut A, Albandar JM (2012) One-year re-entry results of guided bone regeneration around immediately placed implants with immediate or conventional loading: a case series. J Int Acad Periodontol 14(3): 62-68.

34. Benic GI, Jung RE, Siegenthaler DW, Hammerle CH (2009) Clinical and radiographic comparison of implants in regenerated or native bone: 5-year results. Clin Oral Implants Res 20(5): 507-513.

35. Aghaloo TL, Misch C, Lin GH, Iacono VJ, Wang HL, et al. (2016) Bone augmentation of the edentulous maxilla for implant placement: A systematic review. Int J Oral Maxillofac Implants 31 Suppl: s19-s30.

36. Janner SF, Bosshardt DD, Cochran DL, Chappuis V, Huynh Ba G, et al. (2017) The influence of collagen membrane and autogenous bone chips on bone augmentation in the anterior maxilla: a preclinical study. Clin Oral Implants Res 28(11): 1368-1380.

37. Wessing B, Urban I, Montero E, Zechner W, Hof M, et al. (2017) A multicenter randomized controlled clinical trial using a new resorbable non-cross-linked collagen membrane for guided bone regeneration at dehisced single implant sites: interim results of a bone augmentation procedure. Clin Oral Implants Res 28(11): e218-e226.

38. Benic GI, Bernasconi M, Jung RE, Hammerle CH (2017) Clinical and radiographic intra-subject comparison of implants placed with or without guided bone regeneration: 15-year results. J Clin Periodontol 44(3): 315-325.

39. Delgado Ruiz RA, Calvo Guirado JL, Abboud M, Fernandez RMP, MateSanchez JE, Negri B, et al. (2014) Porous titanium granules in critical size 
defects of rabbit tibia with or without membranes. Int J Oral Sci 6(2): 105-110.

40. Benic GI, Ge Y, Gallucci GO, Jung RE, Schneider D, et al. (2017) Guided bone regeneration and abutment connection augment the buccal soft tissue contour: 3-year results of a prospective comparative clinical study. Clin Oral Implants Res 28(2): 219-225.

41. Roos-Jansaker AM, Persson GR, Lindahl C, Renvert S (2014) Surgical treatment of peri-implantitis using a bone substitute with or without a resorbable membrane: a 5-year follow-up. J Clin Periodontol 41(11): 1108-1114.
42. Gultekin BA, Cansiz E, Borahan MO (2017) Clinical and 3-dimensional radiographic evaluation of autogenous iliac block bone grafting and guided bone regeneration in patients with atrophic maxilla. J Oral Maxillofac Surg 75(4): 709-722.

43. Chattopadhyay S, Raines RT (2014) Review collagen-based biomaterials for wound healing. Biopolymers 101(8): 821-833.

44. Caffesse RG, Nasjleti CE, Morrison EC, Sanchez R (1994) Guided tissue regeneration: comparison of bioabsorbable and non-bioabsorbable membranes. Histologic and histometric study in dogs. J Periodontol 65(6): 583-591.

For possible submissions Click below: 